\title{
Central Nervous System Involvement from Epithelial Ovarian Cancer
}

\author{
Gennaro Cormio, Maddalena Falagario and Luigi E. Selvaggi \\ University of Bari \\ Italy
}

\section{Introduction}

Ovarian cancer represents the leading cause of death from gynaecological cancers especially because it relapses in most of the cases.

Central nervous system and especially the encephalon are very often involved in metastatic process arising from malignancies coming from many different sites in the whole body.

The incidence of brain involvement in metastatic tumours was estimated to be around 25\%, that represents a very large proportion and moreover, around $20 \%$ of the lesions found within the central nervous system are diagnosed as secondary locations of a wide spread cancer.

The most common tumours that present brain involvement are lung, breast cancers and melanomas, while the gynaecological malignancies contribute around $2 \%$ of all the brain metastases, except the trophoblastic diseases that involve the central nervous system in around $30 \%$ of the cases.

Anyway, although it was believed that central nervous system involvement from epithelial ovarian cancer was very uncommon, it is increasing of incidence.

Moreover, the comprehension of how to diagnose and treat these metastases is very important because they are usually characterized, more than the most common liver or lung metastases, by symptomatology that can severely affect the quality of life of these patients.

This new finding points out whether or not is appropriate to ask for a brain image technique in the follow up of ovarian cancer patients, and which therapy should these women receive.

Today, there are new possible therapeutic approaches including stereotactic radiosurgery, the administration of new effective and with less side effect chemotherapy agents, moreover the improvement in the neurosurgery techniques makes craniotomy from brain metastases a less riskful procedure with better outcomes.

Aim of his chapter is to analyse the clinicopathological features of these patients, the diagnosis and the different therapeutic approaches based on our experience and on all the series published in literature in the last 15 years. 


\section{Incidence}

Central nervous system involvement from ovarian cancer is an uncommon event, but many studies published in literature agree that it is increasing in incidence. (Cormio, 2011a; Cormio 2011b; Pectasides, 2006)

The analysis of two reports present in literature about the biological behaviour of ovarian cancer in autopsied patients reveals that 1 out of 158 women with this tumour actually present a brain involvement. (Bergman, 1966; Julian, 1974)

In literature, the reported incidence ranges from 0.29 to $4.5 \%$. (Larson, 1986; Stein, 1986; Leroux, 1991; Rodriguez, 1992; Geisler J.P. \& Geisler H.E., 1995; Kaminsky-Forrett, 2000) In our recent series of 20 patients the incidence estimated was 5\%. (Cormio, 2011a)

This increased incidence can be the result of three different aspects. First of all the advances in the production and management of the new chemotherapy agents have guaranteed in the last years a prolongment of life of these patients; this increased time allows the tumour to implant and grow in distant sites. Secondly, the improvement of brain image techniques allowed detecting very small lesions. Finally, the use of chemotherapy agents that seem to pass poorly the blood brain barrier results in the growth of cancer cells within the nervous tissue.

\section{Ways of spread to the central nervous system}

Ovarian cancer usually spreads locally into the peritoneal cavity, while the lymphatic and haematogenous route are possible but rare. Distant metastases are found in about $30 \%$ of patients and the most common localizations are liver, lungs and pleura. (Cormio, 2003a)

The dissemination of the ovarian cancer into the brain seems to occur in three possible way: via the haematogenous spread, by direct invasion of the nervous tissue after bony involvement, or in case of leptomeningeal carcinomatosis, through retrograde lymphatic spread (Pectasides, 2006)

The mechanism of meningeal dissemination is still not known, but hypothetically it should be caused by a direct invasions of the liquor through the choroid plexus, by a rupture of the brain lesions into the ventricles or subarachnoid space, or by infiltration either of the small veins in the arachnoid membrane, either of the lymphatic vessels. (Cormio, 2007).

\section{Clinicopathological characteristics of the primary tumour}

Different series published in literature in the last 15 years, agree that most commonly these metastases arise in patients with an advanced stage (FIGO stage III or IV), serous hystotype and poorly differentiated (G3) primary ovarian cancer (see Table 1). (Anupol, 2002; Brown III, 2005; Chen, 2009; Cohen, 2004; Cormio, 1995, 2003b, Cormio, 2011a; D'Andrea, 2005; Kastritis, 2006; Kim, 2007; Kumar, 2003; Lee, 2008; Sanderson, 2002; Sehouli, 2010; Tay \& Rajesh, 2005). However Kolomainen et al. demonstrated in their series that a brain involvement could be seen quite frequently (one third of their patients) also in patients with FIGO stage I. (Kolomainen, 2002)

The median age at presentation of the ovarian cancer in patients who present brain involvement in the same series is 55,1 years, ranging from 46,7 to 60,3 years.

In most of these studies, patients were treated with the standard procedure consisting in primary optimal debulking surgery followed by platin-based chemotherapy; in particular patients of our recent study received six courses of taxol and carboplatin (Cormio, 2011a) 


\begin{tabular}{|c|c|c|c|c|c|c|}
\hline $\begin{array}{c}\text { Clinical } \\
\text { series (year) }\end{array}$ & $\begin{array}{c}\text { No of } \\
\text { patients }\end{array}$ & Incidence & $\begin{array}{l}\text { Median } \\
\text { age at } \\
\text { ovarian } \\
\text { cancer } \\
\text { diagnosis } \\
\text { (year) }\end{array}$ & $\begin{array}{l}\text { Advanced } \\
\text { stage } \\
\text { disease } \\
\text { (III-IV) }\end{array}$ & $\begin{array}{c}\text { Poorly } \\
\text { differentiated, } \\
\text { G3 cancer }\end{array}$ & $\begin{array}{c}\text { Serous } \\
\text { hystotype }\end{array}$ \\
\hline $\begin{array}{c}\text { Cormio } \\
\text { (1995) }\end{array}$ & 23 & - & 59 & $20(87 \%)$ & 17 (74\%) & $14(61 \%)$ \\
\hline $\begin{array}{c}\text { Anupol } \\
(2002)\end{array}$ & 15 & $1,4 \%$ & 58 & $15(100 \%)$ & $12(80 \%)$ & $14(93,3 \%)$ \\
\hline $\begin{array}{l}\text { Pothuri } \\
\text { (2002) }\end{array}$ & 14 & - & 59,3 & $13(92,8 \%)$ & $10(71,4 \%)$ & $9(64,3 \%)$ \\
\hline $\begin{array}{c}\text { Sanderson } \\
(2002)\end{array}$ & 13 & $1,1 \%$ & 55 & $13(100 \%)$ & - & $3(23 \%)$ \\
\hline $\begin{array}{c}\text { Cormio } \\
(2003)\end{array}$ & 20 & - & 54 & $20(92 \%)$ & $12(55 \%)$ & $15(68 \%)$ \\
\hline $\begin{array}{c}\text { Kumar } \\
(2003)\end{array}$ & 18 & $2,7 \%$ & 54 & $16(88,9 \%)$ & $11(55,5 \%)$ & $13(72,2 \%)$ \\
\hline $\begin{array}{l}\text { Cohen } \\
(2004)^{1}\end{array}$ & 72 & $0,9 \%$ & 50,4 & $52(81 \%)$ & $52(83 \%)$ & $14(24 \%)$ \\
\hline $\begin{array}{l}\text { D'Andrea } \\
\text { (2005) }\end{array}$ & 11 & - & 60,3 & 0 & - & $11(100 \%)$ \\
\hline $\begin{array}{c}\text { Tay \& } \\
\text { Rajesh } \\
(2005)\end{array}$ & 4 & $0,66 \%$ & 52,5 & $3(75 \%)$ & - & $2(50 \%)$ \\
\hline $\begin{array}{c}\text { Brown III } \\
(2005)\end{array}$ & 3 & - & 46,7 & $3(100 \%)$ & - & $2(66,7)$ \\
\hline $\begin{array}{l}\text { Kastritis } \\
(2006)^{2}\end{array}$ & 8 & $3 \%^{2}$ & 59 & $8(100 \%)$ & $6(75 \%)$ & $6(75 \%)$ \\
\hline Kim (2007) & 13 & $2,7 \%$ & 52 & $12(92,3 \%)$ & $7(53,8 \%)$ & $9(69,2 \%)$ \\
\hline Lee (2008) & 15 & $1 \%$ & 55 & $14(93,3 \%)$ & - & $8(53,3 \%)$ \\
\hline $\begin{array}{c}\text { Sehouli } \\
(2010)\end{array}$ & 74 & $1,7 \%$ & 53,9 & $62(83,8 \%)$ & $43(58,1 \%)$ & $53(71,6 \%)$ \\
\hline Chen (2011) & 10 & $1,9 \%$ & 56,6 & $9(90 \%)$ & $6(60 \%)$ & $7(70 \%)$ \\
\hline $\begin{array}{l}\text { Cormio } \\
\text { (2011a) }\end{array}$ & 20 & $5 \%$ & 55.5 & $19(95 \%)$ & $15(75 \%)$ & $14(70 \%)$ \\
\hline
\end{tabular}

- data not available

${ }^{1}$ this study analyses all the ovarian cancer patients and not just the epithelial ones. Anyway most of patients with CNS metastases, when data were available, had a epithelial hystotype (about 93\%)

2 this study analyses only patients presented with brain involvement as isolated site of relapse, for this reason we decided not to include the incidence here calculated in the final results

Table 1. Clinicopathological characteristics of the primary ovarian cancer. 


\section{Clinicopathological characteristics of brain metastases}

\subsection{Pathology}

Metastatic tumour to the brain can involve the Dura Mater and the cranial bones arising especially from breast or prostatic cancer, the leptomeninges leading to a meningeal carcinomatosis, the encephalon or the spinal cord. Metastases in the encephalon usually involve the cerebral and cerebellar hemispheres, less frequently the brainstem and the basal ganglia. Brain metastases usually arise in the zone within the cortex and the white substance that is very vascularized, only rarely they arise deeply.

Macroscopically brain metastases usually appear as grey-red nodular lesions, with or without necrotic or haemorrhagic areas. (Maiuri, 1992)

Central nervous system metastases from epithelial ovarian cancer are usually multiple and localized into the brain hemispheres, followed by the cerebellum; rarely they involve the spinal cord or a leptomeningeal dissemination is discovered. The median interval from the time of primary cancer diagnosis to the brain involvement findings is 32 months in published studies, but in some patients the brain metastases can be found as the first manifestation of the tumour, and only a deep investigation can reveal the ovarian origin. The majority of these women usually present extracranial localizations of the disease, within or not the peritoneal cavity. (See Table 2, Figures 1, 2, 3, 4)

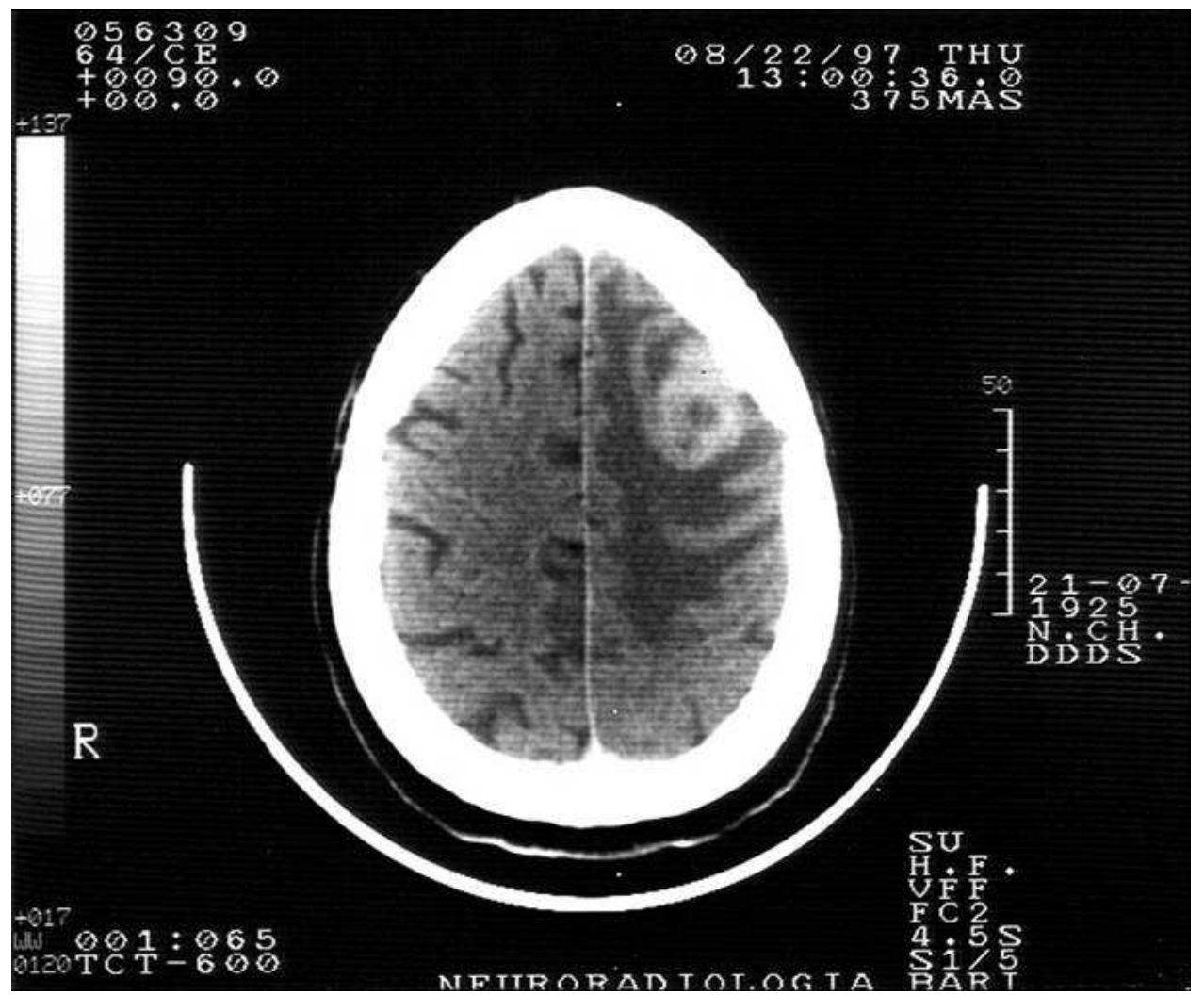

Fig. 1. Cerebral metastases from epithelial ovarian cancer. 


\begin{tabular}{|c|c|c|c|c|c|c|c|}
\hline \multirow{2}{*}{$\begin{array}{c}\text { Clinical series } \\
\text { (year) }\end{array}$} & \multirow{2}{*}{$\begin{array}{c}\text { Mean } \\
\text { interval to } \\
\text { CNS } \\
\text { metastases } \\
\text { (months) }\end{array}$} & \multirow{2}{*}{\begin{tabular}{|c|} 
Patients \\
with \\
extracranial \\
disease $(\%)$
\end{tabular}} & \multicolumn{2}{|c|}{$\begin{array}{l}\text { Number of } \\
\text { CNS lesions }\end{array}$} & \multicolumn{3}{|c|}{ Localization } \\
\hline & & & Single & Multiple & Cerebral & Cerebellar & $\begin{array}{c}\text { Miscellaneous } \\
\text { meningeal }\end{array}$ \\
\hline $\begin{array}{c}\text { Cormio } \\
\text { (1995) }\end{array}$ & 35 & $\begin{array}{c}14 \\
(61 \%)\end{array}$ & $\begin{array}{c}9 \\
(41 \%)\end{array}$ & $\begin{array}{c}13 \\
(59 \%)\end{array}$ & $\begin{array}{c}18 \\
(78,3 \%)\end{array}$ & $\begin{array}{c}4 \\
(17,4 \%)\end{array}$ & $\begin{array}{c}1 \\
(4,3 \%)\end{array}$ \\
\hline $\begin{array}{c}\text { Anupol } \\
\text { (2002) }\end{array}$ & 15 & $\begin{array}{c}7 \\
(\%)\end{array}$ & $\begin{array}{c}8 \\
(53,3 \%)\end{array}$ & $\begin{array}{c}7 \\
(46,7 \%)\end{array}$ & - & - & - \\
\hline $\begin{array}{c}\text { Pothuri } \\
\text { (2002) }\end{array}$ & 42 & $\begin{array}{c}8 \\
(57 \%)\end{array}$ & $\begin{array}{c}12 \\
(85,7 \%)\end{array}$ & $\begin{array}{c}2 \\
(14,3 \%)\end{array}$ & $\begin{array}{c}12 \\
(85,7 \%)\end{array}$ & $\begin{array}{c}2 \\
(14,3 \%)\end{array}$ & 0 \\
\hline $\begin{array}{c}\text { Sanderson } \\
(2002)\end{array}$ & 36 & $\begin{array}{c}8 \\
(61,5 \%)\end{array}$ & $\begin{array}{c}8 \\
(61,5 \%)\end{array}$ & $\begin{array}{c}5 \\
(38,5 \%)\end{array}$ & $\begin{array}{c}9 \\
(69,2 \%)\end{array}$ & $\begin{array}{c}2 \\
(11,4 \%)\end{array}$ & $\begin{array}{c}2 \\
(11,4 \%)\end{array}$ \\
\hline $\begin{array}{c}\text { Cormio } \\
\text { (2003) }\end{array}$ & 29 & $\begin{array}{c}13 \\
(59 \%)\end{array}$ & - & - & $\begin{array}{c}18 \\
(82 \%)\end{array}$ & $\begin{array}{c}4 \\
(18 \%)\end{array}$ & 0 \\
\hline $\begin{array}{l}\text { Kumar } \\
\text { (2003) }\end{array}$ & 29 & $\begin{array}{c}13 \\
(72,2 \%)\end{array}$ & $\begin{array}{c}5 \\
(27,8 \%)\end{array}$ & $\begin{array}{c}13 \\
(72,2 \%)\end{array}$ & $\begin{array}{c}13 \\
(72,2 \%)\end{array}$ & $\begin{array}{c}2 \\
(11,1 \%)\end{array}$ & $\begin{array}{c}3 \\
(16,7 \%)\end{array}$ \\
\hline $\begin{array}{l}\text { Cohen } \\
(2004)^{1}\end{array}$ & 22 & $\begin{array}{c}41 \\
(57 \%)\end{array}$ & $\begin{array}{c}25 \\
(35 \%)\end{array}$ & $\begin{array}{c}47 \\
(65 \%)\end{array}$ & $\begin{array}{c}19 \\
(27 \%)\end{array}$ & $\begin{array}{c}6 \\
(8 \%)\end{array}$ & $\begin{array}{c}47,3 \\
(65 \%)\end{array}$ \\
\hline $\begin{array}{c}\text { D'Andrea } \\
(2005)\end{array}$ & 21 & 0 & $\begin{array}{c}11 \\
(100 \%)\end{array}$ & 0 & $\begin{array}{c}9 \\
(81,8 \%)\end{array}$ & $\begin{array}{c}2 \\
(18,2 \%)\end{array}$ & 0 \\
\hline $\begin{array}{c}\text { Tay \& Rajesh } \\
\text { (2005) }\end{array}$ & 16,5 & $\begin{array}{c}4 \\
(100 \%)\end{array}$ & 0 & $\begin{array}{c}4 \\
(100 \%)\end{array}$ & $\begin{array}{c}1 \\
(25 \%)\end{array}$ & 0 & $\begin{array}{c}3,1 \\
(75 \%) \\
\end{array}$ \\
\hline $\begin{array}{c}\text { Brown III } \\
(2005)\end{array}$ & 19 & 0 & $\begin{array}{c}1 \\
(33,3 \%)\end{array}$ & $\begin{array}{c}2 \\
(66,7 \%)\end{array}$ & 0 & $\begin{array}{c}1 \\
(33,3 \%)\end{array}$ & $\begin{array}{c}2 \\
(66,7 \%)\end{array}$ \\
\hline $\begin{array}{c}\text { Kastritis } \\
(2006)^{2}\end{array}$ & 17,2 & 0 & $\begin{array}{c}4 \\
(50 \%)\end{array}$ & $\begin{array}{c}4 \\
(50 \%)\end{array}$ & - & - & - \\
\hline $\begin{array}{c}\text { Kim } \\
(2007)\end{array}$ & 28 & $\begin{array}{c}7 \\
(53,8 \%)\end{array}$ & $\begin{array}{c}2 \\
(15,4 \%)\end{array}$ & $\begin{array}{c}11 \\
(84,6 \%)\end{array}$ & $\begin{array}{c}6 \\
(46,2 \%)\end{array}$ & $\begin{array}{c}1 \\
(7,7 \%)\end{array}$ & $\begin{array}{c}6 \\
(46,1 \%)\end{array}$ \\
\hline $\begin{array}{c}\text { Lee } \\
(2008)\end{array}$ & $28^{3}$ & $\begin{array}{c}5 \\
(33,3 \%)\end{array}$ & $\begin{array}{c}5 \\
(33,3 \%)\end{array}$ & $\begin{array}{c}10 \\
(66,7 \%)\end{array}$ & - & - & - \\
\hline $\begin{array}{l}\text { Sehouli } \\
\text { (2010) }\end{array}$ & 28,8 & $\begin{array}{c}35 \\
(47,3 \%)\end{array}$ & $\begin{array}{c}26 \\
(21,4 \%)\end{array}$ & $\begin{array}{c}48 \\
(64,8 \%)\end{array}$ & - & - & - \\
\hline $\begin{array}{l}\text { Chen } \\
\text { (2011) }\end{array}$ & 24,3 & $\begin{array}{c}7 \\
(70 \%)\end{array}$ & $\begin{array}{c}1 \\
(10 \%)\end{array}$ & $\begin{array}{c}9 \\
(90 \%)\end{array}$ & & & \\
\hline $\begin{array}{l}\text { Cormio } \\
\text { (2011a) }\end{array}$ & 32,7 & $\begin{array}{c}11 \\
(55 \%)\end{array}$ & $\begin{array}{c}11 \\
(55 \%)\end{array}$ & $\begin{array}{c}9 \\
(45 \%)\end{array}$ & $\begin{array}{c}9 \\
(45 \%)\end{array}$ & $\begin{array}{c}5 \\
(25 \%)\end{array}$ & $\begin{array}{c}6 \\
(30 \%)\end{array}$ \\
\hline
\end{tabular}

- data not available

${ }^{1}$ this study analyses all the ovarian cancer patients and not just the epithelial ones. Anyway most of patients with CNS metastases, when data were available, had a epithelial hystotype (about 93\%)

2 this study analyses only patients presented with brain involvement as isolated site of relapse, for this reason we decided not to include the incidence here calculated in the final results

${ }^{3}$ in this value are excluded two patients whose brain involvement was discovered at the same time of the ovarian cancer findings

Table 2. Clinicopathological characteristic of the brain metastases. 


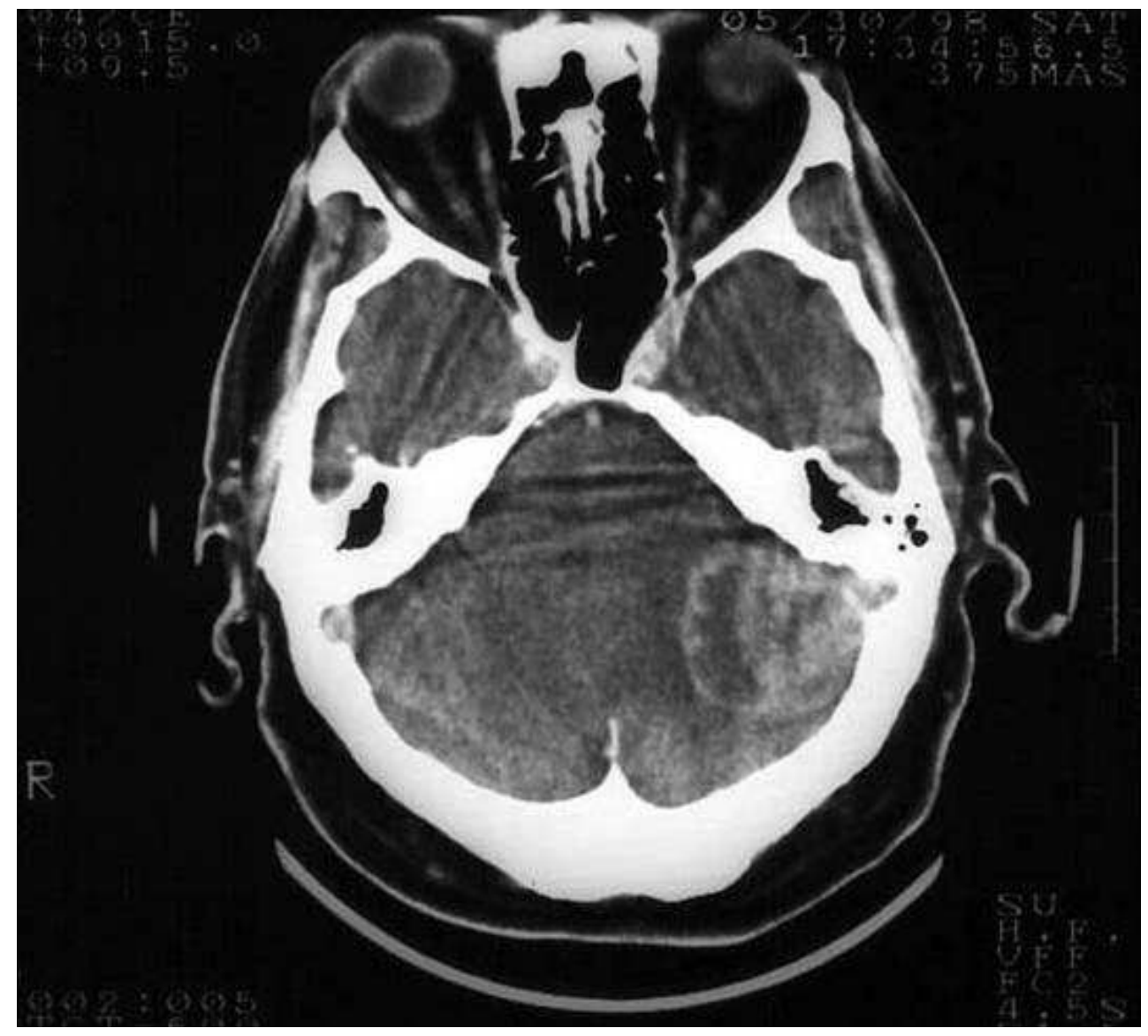

Fig. 2. Cerebellar metastases from epithelial ovarian cancer. 


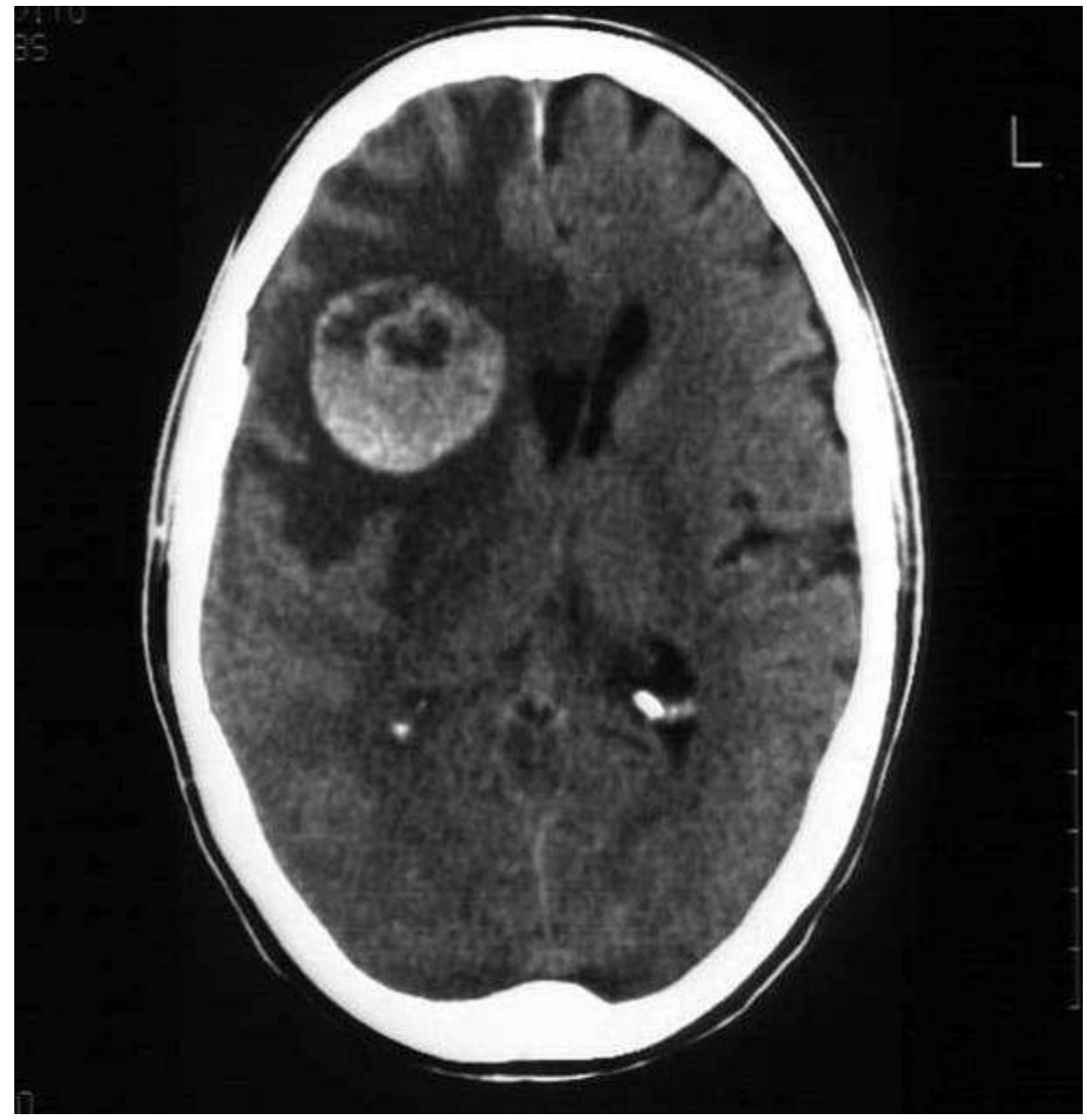

Fig. 3. Single brain metastases from epithelial ovarian cancer. 


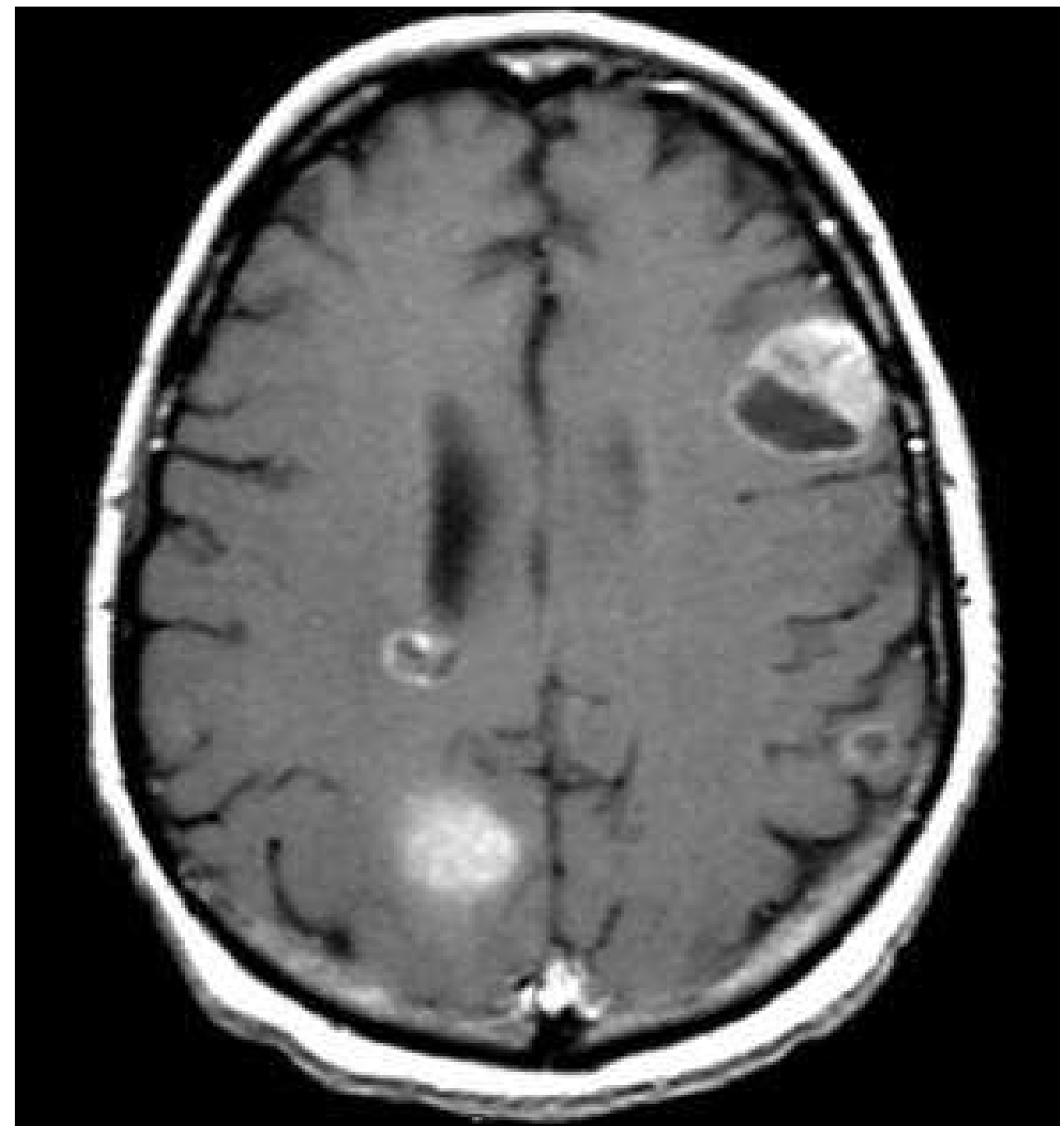

Fig. 4. Multiple brain metastases from epithelial ovarian cancer.

\subsection{Clinical manifestations}

The symptoms at the diagnosis of these metastases, like all central nervous system tumours, can be mild usually with an unspecific symptomatology or severe with, for example epilepsy or focal neurological deficit.

In some cases the metastases can be diagnosed after a stroke, caused by an embolism of cancer cells; in these cases usually the patients at first complain of some sort of neurological deficit that can resolve in few days, but some weeks after the clinical manifestations get quickly worse for the implant and growth of the cancer. (Maiuri, 1992) 
Patients with central nervous system dissemination from ovarian cancer most commonly complain of headache, which is probably a consequence of the increased intracranial pressure caused by the oedema or the hydrocephalus, more then a consequence of the mass of the lesion itself.

Other symptoms that are often described are vomiting, confusions, visual disturbances, paresis, and weakness, loss of consciousness, seizures, and dizziness. (Cohen, 2004; Cormio, 2003; Cormio, 2011a; D'Andrea, 2005; Lee, 2008; Pectasides, 2006; Tay \&Rajesh, 2005)

The leptomeningeal involvement usually causes an arise of the intracranial pressure associated with hydrocephalus; these patients more frequently than the others complain also for bowel of bladder dysfunctions, while the involvement of cranial nerves can also be possible. (Pectasides, 2006; Vitaliani R, 2009)

In our recent series of 20 patients, all patients were symptomatic at the moment of the diagnosis; most of them complain of headache, vomiting and dizziness with or without balance disturbances, less frequent symptoms were diplopia, convulsions, amnesia, confusion and pain. One patient had a left hemiparesis caused by a metastases localized in the right parietal lobe. (Cormio, 2011a)

\section{Diagnosis}

The diagnosis is usually suspected when a patient with ovarian cancer complains about any neurological symptoms, although asymptomatic cases are not infrequent. The symptoms themselves can already also suggest the localization of the lesions in some cases.

\subsection{Imaging features}

It is necessary, in our opinion, to perform either a computed tomography (CT) scan or a magnetic resonance imaging (MRI) in any patient with a history of ovarian cancer, who has any neurological defect.

Usually the first diagnosis is done both by the clinical examination that reveals neurological signs and by pre and post contrast CT scan, less commonly clinicians ask for an MRI.

The two image techniques are both effective, even if MRI seems to be the modality of choice because it has an higher resolution than CT scan, it is able to detect lesions as small as 1,9 $\mathrm{mm}$; moreover MRI seems to be more effective especially for the image study of the lesions localized in the posterior fossa. (Pectasides, 2006).

In a CT scan, metastatic lesions appear as ring areas, singular or multiple, slightly hyper dense, homogeneous or not and commonly surrounded by oedema. Sometimes the metastases can have a hypo dense core for the presence of central necrosis or of a central abscess, which can sometimes simulate the diagnosis of an inflammatory abscess.

The administration of an intravenous contrast medium has been shown to enhance the sensitivity of the technique, moreover Davis et al also demonstrated that a delaying imaging after the administration and an increased volume of contrast also can increase the detection rate. (Davis, 1991)

In MRI the brain metastases appear as hypo intense nodular areas, the administration of the contrast medium (gadolinium) enhances the intensity in the image.

The most important differential diagnosis should be done with primary brain tumours, vascular conditions like strokes or haemorrhages and intracranial abscess. 
Metastatic lesions, usually, can be differentiated from primary central nervous system tumours, because more frequently they are multiple and surrounded by larger areas of oedema (larger than primary tumours of the same size). Finally, the metastatic lesions Further studies should investigate the benefits of using new image techniques as positron emission tomography or magnetic resonance spectroscopy for the diagnosis of central nervous system involvement from epithelial ovarian cancer.

\subsection{Leptomenigeal carcinomatosis}

The meningeal carcinomatosis from epithelial ovarian cancer is often difficult to diagnose, in fact CT scans even with contrast medium injection can be negative.

CT images usually show the presence of solid areas in the parenchyma and hydrocephalus (Chung, 2001), but not directly the presence of leptomeningeal metastases. For this reason the presence of meningeal involvement should be suspected in patient with ovarian cancer and hydrocephalus, and further investigations should be performed.

The image of choice in these patients is the contrast enhanced MRI, while the non-contrast one has been showed to be as ineffective as CT scan. (Collie, 1999)

In patients with meningeal carcinomatosis the diagnosis can be done also by the cytological analysis of the cerebrospinal fluid that reveal the presence of ovarian cancer malignant cells. (Pectasides, 2006)

\subsection{The role of $\mathrm{Ca} 125$}

The serum marker Ca125 is the strongest tumour marker for the presence of ovarian cancer. An increased value of Ca125 can be or not observed in patients with brain involvement from ovarian cancer.

In our experience we noticed that usually it arises in patients with brain involvement, who were already found to have high concentration of the tumour marker at the first diagnosis of the ovarian cancer, even if sometimes it arises also in patients without an history of increased Ca125, or it does not arise in patients for whom this lab value was used as a strong and efficient marker of the presence of the cancer during the previous therapies.

In any case, as for the primary ovarian cancer in patients with positive Ca125, this marker can be used during and after the therapy of the brain metastases in order to assess the response of the cancer to the treatment and the presence or absence of the disease during the follow up.

\section{Therapy}

\subsection{Treatments options and clinical decisions}

When it comes to decide about the different types of treatments, the first things to think about is the quality of life of these patients, in fact in very few cases limited to those patients with a good performance status, single metastases and without any sign of extracranial disease the intent of the therapy can be curative.

As already showed, a large proportion of these patients present with extracranial disease and multiple metastases, in these women it is very unlikely that any treatment of central nervous system metastases chosen can be curative, so the primary roles of the therapy must be the improvement of symptoms, the avoidance of life threatening conditions and the increase of life expectance.

Moreover, other important things to consider are the patients performance status, age, status of the disease, previous treatments and their results. All these aspects added to the 
clinicopathological characteristics of the metastatic brain lesions should be strictly studied to assess the risk-benefit of each treatment modality.

Treatment options are: in emergency the therapy of the life threatening complications like increased intracranial pressure, obstructing hydrocephalus and severe epilepsy, no treatment in patients not eligible of any therapy, corticosteroids, radiotherapy administrated as whole brain radiotherapy or stereotactic radiosurgery, surgery and chemotherapy.

Due to the rarity of these metastases, this condition has not already had any guidelines that can be followed in the choice of treatment, for this reason is very important that the expert gynaecologist oncologist cooperate with the neuroradiologist and the neurosurgeon in order to decide what is best management for each patients with brain involvement from epithelial ovarian cancer.

\subsection{Corticosteroids, mannitol and antiepileptic agents}

The intracranial oedema is very common in women with brain metastases from epithelial ovarian cancer; it results from the damage of the blood brain barrier caused by the tumour itself that leads to an increase of the barrier permeability, with a passage of sodium and water molecules into the brain tissues.

For this reason almost all patients with this condition is eligible of receiving corticosteroids therapy just after the first diagnosis of brain involvement. In fact, corticosteroids are very effective drugs especially in reducing the surrounded oedema of these metastatic lesions, resulting in a decrease of intracranial pressure.

The mechanism of action of corticosteroids is to decrease the oedema by decreasing the permeability of the blood brain barrier and the passage of water and ions into the cerebral parenchyma. This drugs in long term administrations can lead to severe side effects like diabetes and hyperglycaemia, osteoporosis, hypertension, thyroid deficiency, hypogonadism and male impotence, cataract and several others.

The preferred molecule is the dexamethasone because of its lower mineralocorticoids effects that results in fewer side effects. The starting dose is usually $4 \mathrm{mg}$ administered intravenously or orally 4 times daily, after the stabilization of the clinical manifestations the dose should be gradually decreased in a long period of few weeks, to reduce the side effects of a long corticosteroid treatment on the entire metabolism of the patients.

Corticosteroids administered in patients with metastatic brain involvement from epithelial ovarian cancer, results in few hours (usually 6- 24 hours) in the improvement of the headache and the generalized neurological symptoms, while the focal neurological deficits are less effectively improved.

The maximum result is seen usually after few days of corticosteroids treatment, but in a large number of patients their action lasts after some days from the end of the administration.

Mannitol is an osmotic diuretic that administered intravenously is effective in reducing intracranial pressure in acute cases, but with repeated administration can give a rebound effect and worsen the oedema, for this reason is used only for acutely decompensating patients in association to corticosteroids.

Some patients with brain involvement from ovarian cancer can develop convulsions and epilepsy. The prophylactic use of anticonvulsant agents is not indicated, but in patients who present epilepsy these should be administered; the most common drugs used in the clinical practice are the valproate, phenobarbital, phenytoin and carbamazepine. Phenytoin is our 
anticonvulsant of choice because it is usually effective, well tolerated and it can be administered both parenterally and orally.

Corticosteroids and mannitol with or without valproate or other antiepileptic drugs are usually administered in patients with multiple metastases and bad clinical conditions. Several studies present in literature demonstrated that the median survival after brain metastases involvement diagnosis in patients treated with corticosteroids alone is about 2 months, and that this value is similar to the median survival obtained in patients treated with palliative therapy with any kind of central nervous system metastatic disease. (Cohen, 2004; Kaminsky-Forrett, 2000; Pectasides, 2005; Pectasides, 2006; Markesbery, 1978; Ruderman, 1965)

\subsection{Radiotherapy}

The irradiation of the entire brain (whole brain radiotherapy) has been considered for years alone or after surgery, or with chemotherapy the modality of choice in the treatment of metastatic malignancies to the brain with or without extracranial disease. The standard dose for patients who are not eligible of surgery is 30 Gy administered in 10 fractions over a period of 2 weeks. Higher daily doses can be administered to reduce the duration of the treatment, but they cause more commonly a late onset encephalopathy, a severe condition that should be avoided especially in patients with a higher life expectancy. (Dropcho, 1991; Rottenberg, 1977).

This therapeutic approach can actually increase survival and relieve symptoms by reducing the oedema. It is effective in most patients on the headache, convulsions, cognitive and other neurological deficiency, moreover it also let to decrease the corticosteroids doses. Series of patients present in literature who received a uni modal treatment consisting only in whole brain radiotherapy revealed that it leads to a median survival of about 5 months, ranging from 1,5 to 27 months. (Cohen, 2004; Kaminsky-Forrett, 2000; Kumar, 2003; Pectasides, 2006; Sood, 1996)

\subsection{Stereotactic radiosurgery}

Stereotactic radiosurgery represents an important alternative to the surgical approach. It is a special form of radiotherapy where high doses of radiatons are delivered to the metastases using a linear accelerator or, in gamma knife radiosurgery, using a gamma knife without any surgical incision. (Edwend, 2001; Lassman, 2003; Monaco, 2008; Yo Kyung Lee, 2008) The administered dose is inversally proportioned to the diameter of the lesion; usually for lesions smaller than $3 \mathrm{~cm}$ the dose is 18-20 Gy. These metastases are usually small, circular and with radiological margins well defined. More than primary brain tumours, metastatic brain tumours are suitable of being treated with stereotactic radiosurgery. (Soffietti, 2002) Stereotactic surgery has been proven in several reports to be a good therapeutic approach for patients with brain metastases, because these cause rapid reduction of the symptomatology and of the dimensions of the lesions, with lower invasiveness.

This radiotherapy technique has a lower morbidity than surgical approach and so can be admistered also in local anesthesia in patients with systemic clinical conditions that are not suitable for general anesthesia; moreover it has also economic advantages because it does not required hospitalization.

When comparing radiosurgery with whole brain radiotherapy, it is proven that the first one has less long term side effects, such as cognitve problems. 
Patients who are eligible for it are especially those with small metastases, deep seated and so surgically inaccesible lesions. (Monaco, 2008; Combs, 2004)

Anyway, there are some controversial in literature about the role of stereotactic radiosurgery, for example studies showing that these techniques does not have any impact on survival (Andrews, 2004) or that it improves outcomes only in patients with single metastases and not with multiple ones. (Pectasides, 2006)

In conclusion, for these reasons stereotactic radiosurgery is now preferred for those patients who are not eligible for surgery, with single lesions or with deep seated surgically inaccesible metastases.

\subsection{Surgery}

Surgical management can be used with different aims. First of all it can be used in case the diagnosis is not clear, in fact the histological examination done after surgery can clarify the diagnosis especially in those cases where the brain involvement is the first sign of the ovarian cancer and there is no clear evidence of the presence of the primary disease. Secondly, surgical approach can be also used to reduce the symptoms by removing the lesions and so the pressure that the mass causes on the brain parenchyma. Finally, surgery can be used with curative aims or in every case it is necessary to control the local intracranial disease to improve the clinical conditions and let clinicians administer other treatments for the systemic disease.

Many studies demonstrated that the surgical approach represents the best treatment modality for patients with brain involvement from epithelial cancer that are eligible for it. (Cormio, 2003; Cormio, 2011a; Cormio, 2011b; Pothuri, 2002)

For patients who are not good candidates, with extracranial sign of disease or multiple metastases, craniotomy can control symptomatology, avoid life-threatening complications; improve quality of life and also overall survival. (Buckner, 1992; Pectasides, 2006)

In a series of 56 patients, treated in our centre, with a diagnosis of central nervous system metastases from ovarian carcinoma, 22 underwent surgical resection of solitary brain metastases and survived 16 months, while the other 34 women, who were not eligible for surgery, survived only 4 months. (Cormio, 2003)

In conclusion the surgical approach should be chosen always if there are the following conditions:

- the cerebral metastases are single and superficial

- There are no radiological signs of the presence of the disease at other sites, or the activity of the primary tumour is well control

- The clinical conditions of the patients are good

\subsection{Chemotherapy}

The role of chemotherapy in the treatment of brain metastases from ovarian cancer is still on debate. As already précised above, the increasing rate of these metastases observed in the last few years has been attributed to chemotherapy drugs. (Lassman, 2003; Lesser, 1996).

This therapeutic approach has some advantages, such as the simple way of administration that in most cases can be done on outpatient basis or with few days hospitalization, its action on cancer cells that can be eventually presents in the whole body and the fact that it does not damage the brain tissues causing dementia or brain atrophy (Pectasides, 2006) 
On the other side, the poor clinical conditions of some patients, the aggressivity of these treatments and the fact that many chemotherapy agents seem not to pass the blood brain barrier can contraindicate this procedure.

Many authors demonstrated that chemotherapy actually results in a remission of the disease and in an increased survival (Cooper, 1994; Cormio, 1995, Rodriguez, 1992; Watanabe, 2005)

An analysis conducted on 15 studies by Mc Meekin et al showed that chemotherapy has an important role because is the only therapeutic approach that, as the surgical treatment, really improves survival. (Mc Meekin, 2001).

The best choice for their ability to pass the blood brain barrier seem to be cisplatin and other platin-based drugs, etoposide, gemcitabine, docetaxel (Cormio, 1995; Melichar, 2004; Rodriguez, 1992; Vlasved, 1990; Salvati, 1994; Watanabe, 2005)

\subsection{Multimodal approaches}

In our experience but also in several series reported in literature the best approach for patients with brain involvement from epithelial cancer seems to be the multimodal approach; in our recent study, we demonstrated that craniotomy followed by radiotherapy and/or chemotherapy results in median survival of about 18 months. (Cormio, 2011a).

The best multimodal approach is supposed to have a double effect, on one side a local therapy such as craniotomy or stereotactic radiosurgery or whole brain radiotherapy is administered to remove and control the local spread of the cancer within the brain, on the other side the systemic treatment is able to control the wide spread of the disease.

In conclusion, the best combinations of therapies, from our experience, are surgery plus radiotherapy and eventually chemotherapy that in our opinion is the best choice for patients with extracranial disease, stereotactic radiotherapy plus whole brain radiotherapy and eventually chemotherapy.

\subsection{Therapy of neoplastic meningitis}

The neoplastic meningitis has been reported in very few studies, for this reason the therapeutic approach that should be chosen for this patients is currently not defined.

The therapy of neoplastic neoplastic meningitis usually consists in radiotherapy and intracerebrospinal fluid chemotherapy like intrathecal methotrexate (Chamberlain, 2005; Cormio, 2007).

Most patients who present leptomenigeal dissemination of ovarian cancer have also a wide spread dissemination of the disease, with poor clinical conditions and aggressive treatments that are usually indicated in these conditions can give more damages than benefits; for this reason plus the fact that the choice of any clinical approach must take into account first of all the improvement of the quality of life of these patients, the treatment choice is usually very difficult and must be decided for each patients.

\section{Survival and prognostic factors}

Although many efforts and improvements in diagnosis and treatment of central nervous system metastases from epithelial ovarian cancer have been already reached, the prognosis of this condition is still poor. In the studies present in literature the overall survivals 
calculated from the time of the diagnosis of the brain involvement range from 4 to 10 months. (Table 3, Figure 5)

\begin{tabular}{|c|c|}
\hline Clinical series (year) & Survival (months) ${ }^{1}$ \\
\hline Cormio (1995) & 5 \\
\hline Anupol (2002) & 6 \\
\hline Pothuri (2002) & 18 \\
\hline Sanderson (2002) & 4 \\
\hline Cormio (2003) ${ }^{2}$ & 16 \\
\hline Kumar (2003) & 4 \\
\hline Cohen (2004) & 6,27 \\
\hline D'Andrea (2005) ${ }^{3}$ & 28 \\
\hline Tay \& Rajesh (2005) & 19,5 \\
\hline Brown III (2005) & - \\
\hline Kastritis (2006) & - \\
\hline Kim (2007) & 7 \\
\hline Lee (2008) & 14 \\
\hline Sehouli (2010) & 6,2 \\
\hline Chen (2011) & 3 \\
\hline Cormio (2011a) & 17,6 \\
\hline
\end{tabular}

- data not available

1 the survival was calculated from the time of diagnosis of CNS metastases

2 this study analyses only patients with solitary brain metastases who underwent surgical resection

${ }^{3}$ this study analyses only patients treated with surgical en bloc removal and postoperative radiochemotherapy

Table 3. Survival in the series present in literature. 


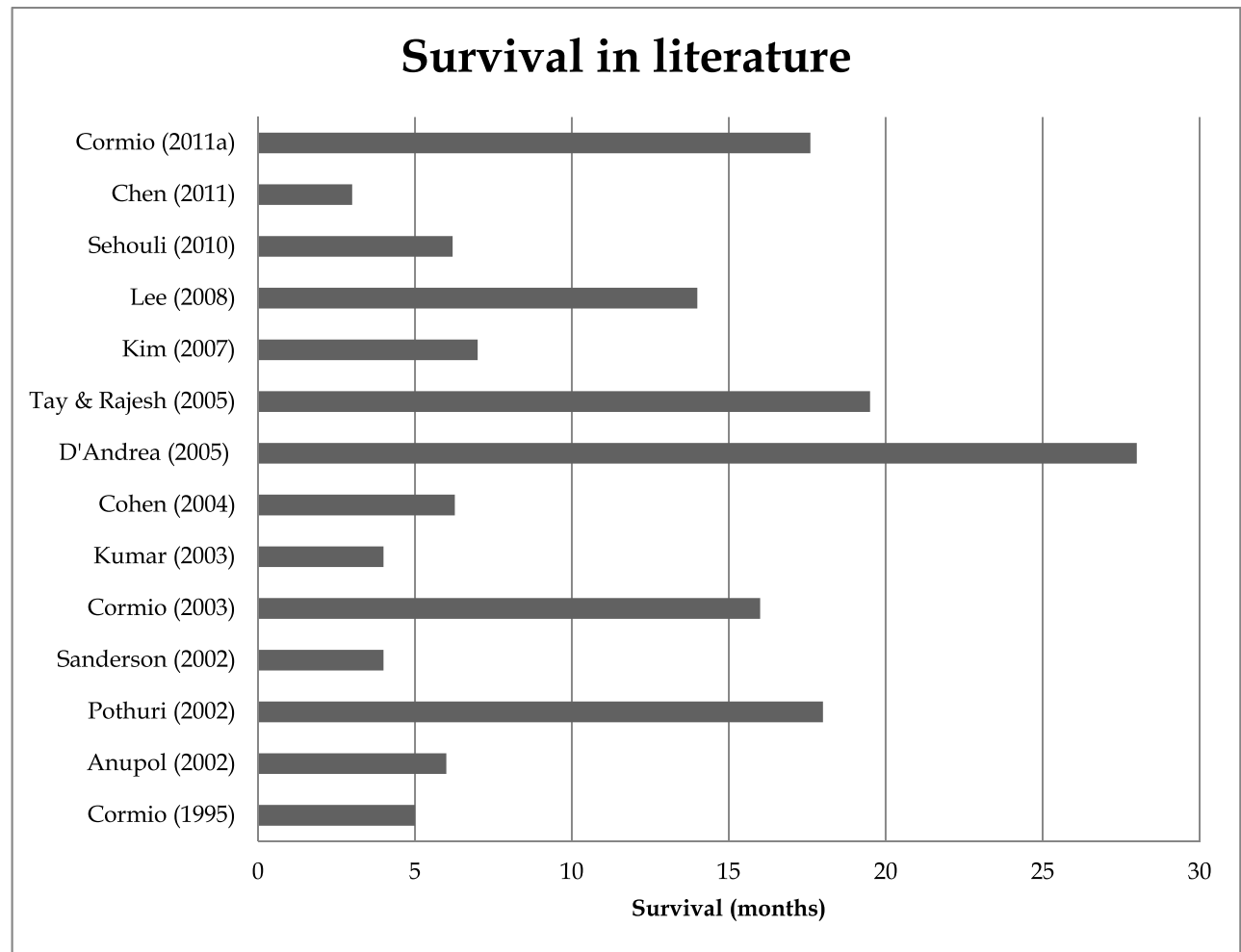

Fig. 5. Survival in the series present in literature.

Different studies present in literature demonstrated that the prognostic factors that significantly affect survival of patients with brain involvement from ovarian cancer are the presence of extracranial disease, the number of brain metastases and the treatment approaches (multi-modal therapy prolong survival in most of the studies. The prognostic factors of each study analysed are shown in Table 4.

\section{Changes from the past and future prospective}

In a recent study (Cormio, 2011b), we compared the a series of patients from 1995 and a series of patients from 2010 all with diagnosis of epithelial ovarian cancer and brain metastases in order to assess the difference in management and outcomes of this condition. We demonstrated that, even if the clinicopathological features both of the primary tumour and the metastases were similar in the two groups, the survival triplicate in the last 15 years going from 5 months to 18 months. This difference can be attributed to the change in the therapeutic approach. In fact, while in 1995 the therapy was given more with palliative intent, nowadays clinicians are more likely to administer more aggressive and multimodal treatments, with the intent of both improving the quality of life and the overall survival. (Anupol, 2002; Brown III, 2005; Chen, 2009; Cohen, 2004; Cormio, 1995; Cormio, 2003b; Cormio, 2011a; D'Andrea, 2005; Kastritis, 2006; Kim, 2007; Lee, 2008; Sanderson, 2002; Sehouli, 2010; Tay \& Rajesh, 2005) 


\begin{tabular}{|c|c|}
\hline Study & Prognostic factors \\
\hline Cormio (1995) & $\begin{array}{l}\text { - number of lesions } \\
\text { - extracranial disease } \\
\text { - treatment (P vs RT vs O RT) }\end{array}$ \\
\hline Anupol (2002) & $\begin{array}{l}\text { - extracranial disease } \\
\text { - treatment (survival with } \mathrm{RT}+\mathrm{O}+\mathrm{CT}>\mathrm{RT}+\mathrm{O} \\
>\mathrm{RT}+\mathrm{CT}>\mathrm{RT} \text { ) }\end{array}$ \\
\hline Cormio (2003) & $\begin{array}{l}\text { - extracranial disease } \\
\text { - interval between ovarian cancer diagnosis and brain } \\
\text { involvement findings } \\
\text { - treatment ( survival with } \mathrm{O}>\text { no } \mathrm{O} \text { ) }\end{array}$ \\
\hline Kumar (2003) & $\begin{array}{l}\text { - serous hystotype } \\
\text { - grade (survival in I-II > III- IV) } \\
\text { - optimal primary surgery } \\
\text { - extracranial disease }\end{array}$ \\
\hline Cohen (2004) & $\begin{array}{l}\text { Univariate analysis } \\
\text { - extracranial disease } \\
\text { - treatment }(\mathrm{RT}+\mathrm{O}>\mathrm{RT} \text { or } \mathrm{O} \text { alone }>\mathrm{P}) \\
\text { Multivariate analysis } \\
\text { - treatment }(\mathrm{RT}+\mathrm{O}>\mathrm{RT} \text { or } \mathrm{O} \text { alone }>\mathrm{P})\end{array}$ \\
\hline Kim (2007) & $\begin{array}{l}\text { Univariate analysis } \\
\text { - Karnofsky performance status }>70 \text { better prognosis } \\
\text { - primary lesion (controlled vs not controlled) } \\
\text { - number of CNS metastases (single > multiple) } \\
\text { - RPA prognostic classification (I >II >III) } \\
\text { - extracranial disease } \\
\text { - treatment (GKRS vs without GKRS) } \\
\text { Multivariate analysis } \\
\text { - RPA prognostic classification }(\mathrm{I}>\mathrm{II}>\mathrm{III}) \\
\text { - treatment (GKRS vs without GKRS) }\end{array}$ \\
\hline Lee (2008) & - treatment (GKRS > WBRT) \\
\hline Sehouli (2010) & $\begin{array}{l}\text { - number of CNS metastases (single }>\text { multiple) } \\
\text { - Karnofsky performance status }>60 \text { better prognosis } \\
\text { - platinum sensitive diseases have better survival } \\
\text { - grading } \\
\text { - FIGO stage } \\
\text { NB: no multimodal therapy and extracranial } \\
\text { metastases }\end{array}$ \\
\hline Cormio (2011a) & $\begin{array}{l}\text { - FIGO stage } \\
\text { - extracranial disease } \\
\text { - treatment }(\mathrm{O}>\text { no } \mathrm{O} \text {; multimodal > unimodal } \\
\text { treatment) } \\
\text { - response after brain metastases therapy (complete > } \\
\text { incomplete or absent) }\end{array}$ \\
\hline
\end{tabular}

Table 4. Prognostic factors in the studies present in literature. 
Future efforts can be put on one side, on the improvement of early diagnosis by the investigation of the role of new imaging techniques such as positron emission tomography and magnetic resonance spectroscopy in the detection of brain metastases, and on the other side on the improvement of treatment modality with higher efficacy and lower morbidity like the new radio surgical techniques. Although many authors agree that a multimodal approach results in better prognosis, further studies should be done to fix some guidelines for the treatment of these patients.

Finally, further studies are also needed to investigate the role of chemotherapy especially in patients with both brain metastases and extracranial metastases from ovarian cancer, in order to find a therapy that can control both the local and systematic manifestations of these cancer.

\section{Conclusions}

In conclusion, even if brain metastases from ovarian cancer have always been considered an uncommon event, they are increasing of incidence. All patients with ovarian cancer who present neurological symptoms must undergo a CT or MRI scan of the brain.

The treatment choice must take into account the clinicopathological characteristics of the metastases and of primary cancer, the presence of extracranial disease and obviously the performance status of the patients. Moreover the therapy should be aim both to have a remission of the disease and to improve the quality of life.

Patients with poor performance status and/or multiple and not isolated metastases usually undergo palliative therapy consisting in mannitol, corticosteroids and anticonvulsant. In patients who are eligible for therapy the possibilities include: craniotomy, stereotactic radiosurgery (including the new gamma knife one), whole brain radiotherapy and chemotherapy. These approaches can be combined in multi-modal treatments.

Although older studies suggested that these patients should undergone only palliative management, in the last 15 year's published studies many authors agree that a multi-modal treatment is the modality of choice in selected patients and can achieve a long-term remission and a better quality of life. (Anupol, 2002; Brown III, 2005; Chen, 2009; Cohen, 2004; Cormio, 1995; Cormio, 2003b; Cormio, 2011a; D'Andrea, 2005; Kastritis, 2006; Kim, 2007; Lee, 2008; Sanderson, 2002; Sehouli, 2010; Tay \& Rajesh, 2005).

An aggressive multimodal approach should be aimed both to cure local and systemic disease and leads to an improvement in duration and quality of life.

Multi centre studies should investigate the better combination of surgery, radiotherapy and chemotherapy giving particular attention to the role of different antineoplastic drugs in order to find a standard treatment for these patients.

\section{References}

Andrews, D. W.; Scott, C. B.; Sperduto P. W.; Flanders, A. E.; Gaspar, L. E.; Schell, M. C.; Werner-Wasik, M.; Demas, W.; Ryu, J.; Bahary, J. P.; Souhami, L.; Rotman, M.; Mehta, M. P.; Curran, W. J. Jr (2004) Whole brain radiation therapy with or without stereotactic radiosurgery boost for patients with one to three brain metastases: phase III results of the RTOG 9508 randomised trial. Lancet. 363:1665-1672. 
Anupol, N.; Ghamande, S.; Odunsi, K.; Driscoll, D.; Lele, S. (2002) Evaluation of prognostic factors and treatment modalities in ovarian cancer patients with brain metastases. Gynecologic Oncology. Jun;85(3):487-92.

Bergman, F. (1966) Carcinoma of the ovary: a clinicopathological study of 86 autopsied cases with special reference to mode of spread. Acta Obstetricia et Gynecologica Scandinavica. 45:211-231

Brown, J.V. 3rd; Goldstein, B.H.; Duma, C.M.; Rettenmaier, M.A., Micha J.P. (2005) Gammaknife radiosurgery for the treatment of ovarian cancer metastatic to the brain. Gynecologic Oncology 97:858-861.

Chamberlain, M. C. (2005) Neoplastic meningitis. Journal of Clinical Oncology. 23:3605-3613

Chen, Y.L.; Cheng, W.; Hsieh, C.; Chen, C. (2011)Brain metastasis as a late manifestation of ovarian carcinoma. European Journal of Cancer Care. 20: 44-49

Chung, P.; Allerton, R. (2001) Malignant meningitis secondary to ovarian carcinoma: an unusual occurrence. Clinical Oncology (The Royal College of Radiologists). 13:112 - 113.

Cohen, Z.R.; Suki, D.; Weinberg, J.S.; Marmor, E.; Lang, F.F.; Gershenson, D.M.; Sawaya, R. (2004) Brain metastases in patients with ovarian carcinoma: prognostic factors and outcome. Journal of Neurooncology. Feb; 66(3):313-25.

Collie, D. A.; Brush, J. P.; Lammie, G. A.; Grant, R.; Kunkler, I.; Leonard, R.; Gregor, A.; Sellar, R. J. (1999) Imaging features of leptomeningeal metastases. Clinical Radiology, 54:765 - 771.

Cooper, K. G.; Kitchener, H. C.; Parkin, D. E. (1994) Cerebral metastases from epithelial ovarian carcinoma treated with carboplatin. Gynecologic Oncology. 55:318-323.

Cormio, G.; Maneo, A.; Parma, G.; Pittelli, M.R.; Miceli, M.D.; Bonazzi, C. (1995) Central nervous system metastases in patients with ovarian carcinoma. Annals of Oncology 6:571-574.

Cormio, G.; Loizzi, V.; Selvaggi, L.E. (2007) Leptomeningeal involvement after remission of brain metastases from ovarian cancer. International Journal of Gynaecology $\mathcal{E}$ Obstetrics. Nov;99(2):139.

Cormio, G.; Rossi, C.; Cazzolla, A.; Resta, L.; Loverro, G.; Greco, P.; Selvaggi, L.E. (2003) Distant metastases in ovarian carcinoma. International Journal of Gynecological Cancer. 13(2): 125-9

Cormio, G.; Maneo, A.; Colamaria, A.; Loverro, G.; Lissoni, A.; Selvaggi, L. (2003) Surgical resection of solitary brain metastasis from ovarian carcinoma. An analysis of 22 cases. Gynecologic Oncology 89: 116-119

Cormio, G.; Loizzi, V.; Falagario, M.; Calace, A.; Colamaria, A.; De Tommasi, A.; Selvaggi, L.E. (2011) Central nervous system metastases from epithelial ovarian cancer: prognostic factors and outcomes. International Journal of Gynecological Cancer 21(5):816-21

Cormio, G.; Loizzi, V.; Falagario, M.; Lissoni, A.A.; Resta, L.; Selvaggi, L.E. (2011) Changes in the management and outcome of central nervous system involvement from ovarian cancer since 1994. International Journal of Gynecology and Obstetric 114(2):133-6

D'Andrea, G.; Roperto, R.; Dinia, L.; Caroli, E.; Salvati, M.; Ferrante, L. (2005) Solitary cerebral metastases from ovarian epithelial carcinoma: 11 cases. Neurosurgical Review. Apr;28(2):120-3. 
Davis, P. C.; Hudgins, P. A.; Peterman, S. B.; Hoffman, J. C. Jr. (1991) Diagnosis of cerebral metastases: double-dose delayed CT vs contrast-enhanced MR imaging. American Journal of Neuroradiology Mar-Apr;12(2):293-300

Dropcho, E.J. (1991) Central nervous system injury by therapeutic irradiation. Neurologic Clinics 9:969-988

Ewend, M. G.; Carey, L. A.; Morris D. E.; Harvey, R. D.; Hensing, T. A. (2001) Brain metastases. Current Treatment Options in Oncology. 2:537-547.

Geisler, J.P. \& Geisler, H.E. (1995) Brain metastases in epithelial ovarian carcinoma. Gynecologic Oncology. May;57:246-9.

Julian, C. G.; Goss, J.; Blanchard, K.; Woodruff, J. D.(1974) Biologic behavior of primary ovarian malignancy. Obstetrics \& Gynecology. 44:873-884

Kaminsky-Forrett, M.C.; Weber, B.; Conroy, T.; \& Spaeth, D. (2000) Brain metastases from epithelial ovarian carcinoma. International Journal of Gynecological Cancer 10, 366-371.

Kastritis, E.; Efstathiou, E.; Gika, D.; Bozas, G.; Koutsoukou, V.; Papadimitriou, C.; Pissakas, G.; Dimopoulos, M.A.; Bamias, A. (2006) Brain metastases as isolated site of relapse in patients with epithelial ovarian cancer previously treated with platinum and paclitaxel-based chemotherapy. International Journal of Gynecological Cancer. MayJun;16(3):994-9.

Kim, T.J.; Song, S.; Kim, C.K.; Kim, W.Y.; Choi, C.H.; Lee, J.H.; Lee, J.W.; Bae, D.S.; Kim, B.G. (2007)Prognostic factors associated with brain metastases from epithelial ovarian carcinoma. International Journal of Gynecological Cancer. Nov-Dec;17(6):1252-7.

Kolomainen, D.F.; Larkin, J.M; Badran, M.; A'Hern, R.P.; King, D.M.; Fisher, C.; Bridges, J.E.; Blake, P.R.; Barton, D.P.; Shepherd, J.H.; Kaye, S.B.; Gore, M.E. (2002) Epithelial ovarian cancer metastazing to the brain: a late manifestation of the disease with an increasing incidence. Journal of Clinical Oncology 20, 982-986.

Kumar, L.; Barge, S.; Mahapatra, A. K.; Thulkar, S.; Rath, G. K.; Kumar, S.; Mishra, R.; Dawar, R.; Singh, R. (2003) Central nervous system metastases from primary epithelial ovarian cancer. Cancer Control. May-Jun;10(3):244-53.

Lassman, A. B.; DeAngelis, L. M. (2003) Brain metastases. Neurologic Clinics. 21: 1-23.

Larson, D.M.; Copeland, L.J.; Moser, R.P.; Malone, J.M.; Gershenson, D.M.; Wharton, J.T. (1986) Central nervous system metastases in epithelial ovarian carcinoma. Obstetrics and Gynecology 68, 746-750.

Lee, Y.K.; Park, N.H.; Kim, J.W.; Song, Y.S.; Kang, S.B.; Lee, H.P. (2008) Gamma-knife radiosurgery as an optimal treatment modality for brain metastases from epithelial ovarian cancer. Gynecologic Oncology. Mar;108(3):505-9.

Leroux, P.D.; Berger, M.S.; Elliot, P.; Tamimi, H. (1991) Cerebral metastases from ovarian carcinoma. Cancer 67, 2194-2199.

Lesser, G. J. (1996) Chemotherapy of cerebral metastases from solid tumors. Neurosurgery Clinics of North America. 7:527-536.

Maiuri, F.; D'Andrea, F. (1992) Neurochirurgia (second edition), Editoriale Bios s.a.s., Cosenza, Italy.

Markesbery W. R.; Brooks W. H.; Gupta G. D.; Young A. B. (1978) Treatment for patients with cerebral metastases. Archives of Neurology. 35:754-756.

McMeekin, D. S.; Kamelle, S. A.; Vasilev, S. A.; Tillmanns, T. D.; Gould, N. S.; Scribner, D. R.; Gold, M. A.; Guruswamy, S.; Mannel, R. S. (2001) Ovarian cancer metastatic to the 
brain: what is the optimal management. Journal of Surgical Oncology. 78:194200; discussion 200-201.

Melichar, B.; Urminská, H.; Kohlová, T.; Nová, M.; Cesák, T. (2004) Brain metastases of epithelial ovarian carcinoma responding to cisplatin and gemcitabine combination chemotherapy: a case report and review of the literature. Gynecologic Oncology. Aug;94(2):267-76.

Monaco III, E.; Kondziolka, D.; Mongia, S.; Niranjan, A.; Flickinger, J. C.; Dade Lunsford, L. (2008) Management of brain metastases from ovarian and endometrial carcinoma with stereotactic radiosurgery. Cancer. 113, 9:2610-14.

Pectasides, D.; Aravantinos, G.; Fountzilas, G.; Kalofonos, C.; Efstathiou, E.; Karina, M.; Pavlidis, N.; Farmarkis, D.; Economopoulos, T.; Dimopoulos, M. A. (2005) Brain metastases from epithelial ovarian cancer. The Hellenic Cooperative Oncology Group (HeCOG) experience and review of the literature. Anticancer Research. 25:3553-3558.

Pectasides, D.; Pectasides, M.; Economopoulos, T. (2006) Brain metastases from epithelial ovarian cancer: a review of the literature. The Oncologist. 11:252-260.

Pothuri, B.; Chi, D.S.; Reid, T.; Aghajanian, C.; Venkatraman, E.; Alektiar, K.; Bilsky, M.; Barakat, R.R. (2002) Craniotomy for central nervous system metastases in epithelial ovarian carcinoma. Gynecologic Oncology. Oct;87(1):133-7.

Rodriguez, G.C.; Soper, J.T.; Berchuck, A.; Oleson, J.; Dodge, R.; Montana, G.; ClarkePearson, D.L. (1992) Improved palliation of cerebral metastases in epithelial ovarian cancer using combined modality approach including radiation therapy, chemotherapy and surgery. Journal of Clinical Oncology 10, 1553-1560

Rottenberg, D.A.; Chernik, N.L.; Deck, M.D.; Ellis, F.; Posner, J.B. (1077) Cerebral necrosis following radiotherapy of external neoplasm. Annals of Neurology 1:339-357

Ruderman, N. B.; Hall, T. C. (1965) Use of glucocorticoids in the palliative treatment of metastatic brain tumors. Cancer. 18:298-306.

Salvati, M.; Cervoni, L. (1994) Solitary cerebral metastasis from ovarian carcinoma: report of 4 cases. The Journal of Neuro-Oncology. 19:75-77.

Sanderson, A.; Bonington, S.C.; Carrington, I.M.; Alison, D.L.; Spencer, J.A. (2002) Cerebral metastasis and cerebral events in women with ovarian cancer. Clinical Radiology 57:815-819.

Sehouli, J.; Pietzner, K.; Harter, P.; Münstedt, K.; Mahner, S.; Hasenburg, A.; Camara, O.; Wimberger, P.; Boehmer, D.; Buehling, K.J.; Richter, R.; El Khalfaoui, K.; OskayOzcelik, G. (2010) Prognostic role of platinum sensitivity in patients with brain metastases from ovarian cancer: results of a German multicenter study. Annals of Oncology. Nov;21(11):2201-5

Sood A.; Kumar L.; Sood R.; Sandhu M. S.(1996) Epithelial ovarian carcinoma metastatic to the central nervous system: a report on two cases with review of literature. Gynecologic Oncology. 62:113-118.

Soffietti, R.; Ruda, R.; Mutani, R. (2002) Management of brain metastes. Journal of Neurology 249:1357-1369

Stein, M.; Steiner, M.; Ben-Schachar, M.; Kuten, A.; Malberger, E.; Goldsher, D.; Robinson, E. (1987) Leptomeningeal involvement by epithelial ovarian cancer: a case report. Stein, M.; Steiner, M.; Ben-Schachar, M.; Kuten, A.; Malberger, E.; Goldsher, D.; 
Robinson, E. (1987) Leptomeningeal involvement by epithelial ovarian cancer: a case report. Gynecologic Oncology. Jun;27(2):241-5.Jun;27(2):241-5.

Tay, S.K. \& Rajesh, H. (2005) Brain metastases from epithelial ovarian cancer. International Journal of Gynecological Cancer. Sep-Oct;15(5):824-9.

Vitaliani, R.; Spinazzi, M.; Del Mistro, A. R.; Manara, R.; Tavolato, B; Bonifati, D. M. (2009) Subacute onset of deafness and vertigo in a patient with leptomenigeal metastasis from ovarian cancer. Neurological Science. Feb; 30(1):65-7.

Vlasveld, L. T.; Beynen, J. H.; Boogerd, W.; Ten Bokkel Huinink, W. W.; Rodenhuis, S. (1990) Complete remission of brain metastases of ovarian cancer following high-dose carboplatin: a case report and pharmacokinetic study. Cancer Chemotherapy and Pharmacology. 25:382-383.

Watanabe, A.; Shimada, M.; Kigawa, J.; Iba, T.; Oishi, T.; Kanamori, Y.; Terakawa, N. (2005) The benefit of chemotherapy in a patient with multiple brain metastases and meningitis carcinomatosa from ovarian cancer. International Journal of Clinical Oncology. 10:69-71.

Yoo-Kyung, L. ; Noh-Hyun, P. ; Jae Weon, K. ; Yong-Sang, S. ; Soon-Beom, K. ; Hyo-Pyo, L. (2008) Gamma-knife radiosurgery as an optimal treatment modality for brain metastases from epithelial ovarian cancer. Gynecologic Oncology 108 :505-509. 


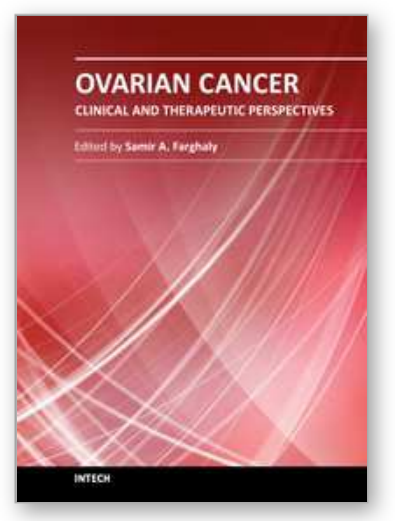

\author{
Ovarian Cancer - Clinical and Therapeutic Perspectives \\ Edited by Dr. Samir Farghaly
}

ISBN 978-953-307-810-6

Hard cover, 338 pages

Publisher InTech

Published online 15, February, 2012

Published in print edition February, 2012

Worldwide, Ovarian carcinoma continues to be responsible for more deaths than all other gynecologic malignancies combined. International leaders in the field address the critical biologic and basic science issues relevant to the disease. The book details the molecular biological aspects of ovarian cancer. It provides molecular biology techniques of understanding this cancer. The techniques are designed to determine tumor genetics, expression, and protein function, and to elucidate the genetic mechanisms by which gene and immunotherapies may be perfected. It provides an analysis of current research into aspects of malignant transformation, growth control, and metastasis. A comprehensive spectrum of topics is covered providing up to date information on scientific discoveries and management considerations.

\title{
How to reference
}

In order to correctly reference this scholarly work, feel free to copy and paste the following:

Gennaro Cormio, Maddalena Falagario and Luigi E. Selvaggi (2012). Central Nervous System Involvement from Epithelial Ovarian Cancer, Ovarian Cancer - Clinical and Therapeutic Perspectives, Dr. Samir Farghaly (Ed.), ISBN: 978-953-307-810-6, InTech, Available from: http://www.intechopen.com/books/ovarian-cancerclinical-and-therapeutic-perspectives/central-nervous-system-involvement-from-epithelial-ovarian-cancer

\section{INTECH}

open science | open minds

\section{InTech Europe}

University Campus STeP Ri

Slavka Krautzeka 83/A

51000 Rijeka, Croatia

Phone: +385 (51) 770447

Fax: +385 (51) 686166

www.intechopen.com

\section{InTech China}

Unit 405, Office Block, Hotel Equatorial Shanghai

No.65, Yan An Road (West), Shanghai, 200040, China

中国上海市延安西路65号上海国际贵都大饭店办公楼 405 单元

Phone: +86-21-62489820

Fax: +86-21-62489821 
(C) 2012 The Author(s). Licensee IntechOpen. This is an open access article distributed under the terms of the Creative Commons Attribution 3.0 License, which permits unrestricted use, distribution, and reproduction in any medium, provided the original work is properly cited. 